\title{
Midday measurements of leaf water potential and stomatal conductance are highly correlated with daily water use of Thompson Seedless grapevines
}

\author{
L. E. Williams $\cdot$ P. Baeza $\cdot$ P. Vaughn
}

Received: 16 July 2010/ Accepted: 23 February 2011/Published online: 16 March 2011

(c) The Author(s) 2011. This article is published with open access at Springerlink.com

\begin{abstract}
A study was conducted to determine the relationship between midday measurements of vine water status and daily water use of grapevines measured with a weighing lysimeter. Water applications to the vines were terminated on August 24th for 9 days and again on September 14th for 22 days. Daily water use of the vines in the lysimeter $\left(\mathrm{ET}_{\mathrm{LYS}}\right)$ was approximately $40 \mathrm{~L}$ vine ${ }^{-1}(5.3 \mathrm{~mm})$ prior to turning the pump off, and it decreased to $22.3 \mathrm{~L}$ vine ${ }^{-1}$ by September 2 nd. Pre-dawn leaf water potential $\left(\Psi_{\mathrm{PD}}\right)$ and midday $\Psi_{1}$ on August 24 th were -0.075 and $-0.76 \mathrm{MPa}$, respectively, with midday $\Psi_{1}$ decreasing to $-1.28 \mathrm{MPa}$ on September 2nd. Leaf $g_{\mathrm{s}}$ decreased from $\sim 500$ to $\sim 200 \mathrm{mmol} \mathrm{m}^{-2} \mathrm{~s}^{-1}$ during the two dry-down periods. Midday measurements of $g_{\mathrm{s}}$ and $\Psi_{1}$ were significantly correlated with one another $(r=0.96)$ and both with $\mathrm{ET}_{\mathrm{LYS}} /$ $\mathrm{ET}_{\mathrm{o}}(r=\sim 0.9)$. The decreases in $\Psi_{1}, g_{\mathrm{s}}$, and $\mathrm{ET}_{\mathrm{LYS}} / \mathrm{ET}_{\mathrm{o}}$ in this study were also a linear function of the decrease in volumetric soil water content. The results indicate that even
\end{abstract}

Communicated by E. Fereres.

L. E. Williams ( $\square)$

Department of Viticulture and Enology,

University of California, Davis, CA, USA

e-mail: williams@uckac.edu

L. E. Williams

Kearney Agricultural Center, 9240 S. Riverbend Avenue,

Parlier, CA 93648, USA

P. Baeza

Departamento de Producción Vegetal: Fitotecnia,

Universidad Politécnica de Madrid, Ciudad Universitaria s/n,

28040 Madrid, Spain

P. Vaughn

Water Management Research Laboratory,

USDA-ARS, Parlier, CA 93648, USA modest water stress can greatly reduce grapevine water use and that short-term measures of vine water status taken at midday are a reflection of daily grapevine water use.

\section{Introduction}

Irrigated agriculture needs to become more water use efficient due to increasing demands and when annual rainfall within a crop production area is below normal (Larus 2004; Morison et al. 2008). This is especially true in California where the competition among environmental, agricultural and urban demands for limited water supplies continues to increase. Grapevines grown at most locations in California are irrigated at least some time during the growing season due to the fact that the majority of rainfall will occur during the dormant portion of the growing season and that grapevine water use will exceed the amount of water held in the soil reservoir (Williams and Matthews 1990). Seasonal evapotranspiration $\left(\mathrm{ET}_{\mathrm{c}}\right)$ of young to mature grapevines grown in the San Joaquin Valley can range from 200 to $800 \mathrm{~mm}$, while estimated $\mathrm{ET}_{\mathrm{c}}$ of mature wine grape vineyards at different locations in California may vary from 450 to $800 \mathrm{~mm}$ per growing season (Williams and Baeza 2007; Williams et al. 2003a, b; Williams and Ayars 2005a, b). Differences in $\mathrm{ET}_{\mathrm{c}}$ among and within the different grape commodities are a function of trellis type and row spacing (Williams and Ayars 2005b).

Fereres and Soriano (2007) have suggested that the potential for water conservation in tree and vine crops may be greater than those of field crops since they are more highly coupled to the atmosphere. However, they also pointed out that the use of deficit irrigation in orchards and vineyards will require close monitoring of soil and/or plant water status so as to minimize risk. There are numerous 
tools one can use to monitor vine water status or assist in scheduling vineyard irrigations (Cifre et al. 2005); Jones 2004).

Currently, the most widely used technique to monitor vine water status in California's commercial vineyards is midday $\Psi_{1}$ and to a lesser extent midday $\Psi_{\text {stem }}$ (L.E. Williams, personal observation). Recently, porometers are being used in the north coast wine production regions (Sonoma and Napa counties) of California by both consultants and growers to aid in irrigation management (R. H. Smith, personal communication). Soil water availability also is being monitored with neutron probes by a few crop consultants, while some grape growers may use tensiometers or electrical resistance type sensors. For the aforementioned techniques to be useful in an irrigation management program, the determination as to whether they are actually correlated with grapevine water use would be beneficial.

A weighing lysimeter was installed in 1986 (Williams et al. 2003a) and used to measure water use of two Thompson Seedless grapevines to develop seasonal crop coefficients for the San Joaquin Valley of California (Williams et al. 2003a, b; Williams and Ayars 2005a, b). During August of 2005, the lysimeter pump was turned off for 9 days, irrigation resumed for 11 days and then the pump turned off a second time for 21 days. During this time frame, midday $\Psi_{1}$ and $g_{\text {s }}$ and soil volumetric water content were measured frequently to determine whether daily grapevine water use during these periods was correlated with these short-term measures of vine/soil water status. Measurements were taken at midday since grapevine stomatal conductance and $\Psi_{1}$ reach their maximum and minimum diurnal values, respectively, during this time frame (Grimes and Williams 1990; Williams and Baeza 2007). It was also felt that limiting these measurements to the two vines growing in the lysimeter would reduce potential plant to plant variation one may encounter in vineyards (van Leeuwen et al. 2006) and orchards (Naor et al. 2006) while accurately measuring water use of mature grapevines with a weighing lysimeter (Allen et al. 1998).

\section{Materials and methods}

A weighing lysimeter was installed at the University of California's Kearney Agricultural Center located in the San Joaquin Valley of California $\left(36^{\circ} 48^{\prime} \mathrm{N}\right.$, lat, $119^{\circ} 30^{\prime} \mathrm{W}$, long.) in 1986. Two Vitis vinifera L. (cv. Thompson Seedless clone 2A) grapevine cuttings were planted in the lysimeter and in the surrounding 1.4-ha $(168 \mathrm{~m} \times 82 \mathrm{~m})$ vineyard on 9 April 1987. The soil was a Hanford fine sandy loam (coarse-loamy, mixed, non-acid, thermic Typic Xerorthent). The trellis of the vines used in the study consisted of a 2.13-m wooden stake driven $0.45 \mathrm{~m}$ into the soil at each vine. A $0.6-\mathrm{m}$ cross-arm was placed atop the stake and wires attached at either end of the cross-arms to support the vine's fruiting canes. Row direction was approximately east/west. A detailed description of the lysimeter and calculations used to measure grapevine evapotranspiration $\left(\mathrm{ET}_{\mathrm{c}}\right)$ are given elsewhere (Williams et al. 2003a, b). Reference ET $\left(\mathrm{ET}_{\mathrm{o}}\right)$ data were obtained from a California Irrigation Management Information System (CIMIS) weather station located $2 \mathrm{~km}$ from the vineyard site. Variables measured and calculations used to determine hourly and daily $\mathrm{ET}_{\mathrm{o}}$ from CIMIS can be found in Synder and Pruitt (1992).

Prior to the initiation of the study, two layers of 30-gauge, clear PVC film (Goss Plastic Film Corp., Los Angeles, CA) were used to cover the soil surface of the lysimeter on August 22 (day of year [DOY] 234) and held in place with weights. The soil remained covered by the plastic throughout the study except on September 13th and 14th (DOYs 256 and 257). On those days, the plastic was rolled to the edges of the lysimeter, exposing the wetted soil surface. Water use of the grapevines in the lysimeter will be designated $\mathrm{ET}_{\mathrm{LYS}}$ to denote the fact that the soil surface was covered with plastic, so as to minimize soil evaporation (Steinberg et al. 1990).

The irrigation pump to the lysimeter was turned off on August 24 (DOY 236) at $1700 \mathrm{~h}$. The pump was turned back on September 2 (DOY 245) at 1800 h. The next day, the lysimeter pump was run for five hours to supply additional water $\left(\sim 120 \mathrm{~L}_{\text {vine }}{ }^{-1}\right)$ to the soil. Thereafter, the lysimeter pump was activated when the vines used the equivalent of $2 \mathrm{~mm}$ of water or $8 \mathrm{~L}$ vine ${ }^{-1}$. The lysimeter pump was turned off again on September 14 (DOY 257) at $1700 \mathrm{~h}$ and remained such until October 4 (DOY 278). The pump was activated for $1.5 \mathrm{~h}$ the next day and then allowed to irrigate as stated above.

Water potential measurements were conducted as described by Williams and Araujo (2002). Specifically, pre-dawn $\Psi\left(\Psi_{\mathrm{PD}}\right)$ measurements began at $\approx 0430 \mathrm{~h}$ and were finished prior to sunrise using a pressure chamber (Model 1000, PMS Instrument Co., Corvallis, Ore.). Midday measurements of leaf water potential $\left(\Psi_{1}\right)$ generally were taken between 1230 and 1330 h, Pacific Daylight Time (PDT). Leaf blades for $\Psi_{\mathrm{PD}}$ and $\Psi_{1}$ determinations were covered with a plastic bag, quickly sealed, and petioles then cut within 1-2 s. The time between leaf excision and chamber pressurization was generally <10-15 s. Leaves, chosen for $\Psi_{\mathrm{PD}}$ and $\Psi_{1}$ were fully expanded and mature. At midday, $\Psi_{1}$ was measured on leaves exposed to direct solar radiation located on the top or south sides of the canopy. Two to three leaves from each of the lysimeter vines were measured and used for data analyses. While the number of leaves removed from each vine in the lysimeter 
to measure $\Psi_{1}$ would have been upwards of 60 per vine, the total number of leaves from primary shoots on a mature Thompson Seedless grapevine can be greater than 1,500 (Williams 1987) with a total leaf area in excess of $20 \mathrm{~m}^{2}$ vine $^{-1}$ (Williams 1987; Williams et al. 2003b, 2010a). Therefore, the removal of these leaves would only have had a minimal effect, if any, on water use and/or water status of these vines.

The difference between measured $\Psi_{1}$ of the lysimeter vines on a particular day and a fully irrigated $\Psi_{1}$ baseline as a function of vapor pressure deficit (VPD) at the time of measurement was calculated. The equation used to determine the fully irrigated baseline, taken from Williams and Baeza (2007), was:

Fully irrigaed $\Psi_{1}=-0.49-0.079 \times \mathrm{VPD}$

Stomatal conductance $\left(g_{\mathrm{s}}\right)$ was measured with a steadystate diffusion porometer (Model 1600, LiCor, Lincoln, $\mathrm{NE}$ ) on leaves similar to those used for $\Psi_{1}$ measurements. Measurements were taken on four to five leaves per vine. Temperature and relative humidity at the location of the lysimeter were measured with two temperature/relative humidity probes (Model DM-84 Multimeter with a MultiMeterMate RH/T probe, using a Vaisala HUMIDCAP ${ }^{\circledR}$ RH sensor, A.W. Sperry Inst., Inc., Hauppauge, NY). The probes were positioned just beneath the canopy of the two vines on either side of the lysimeter (making sure they were in the shade).

Soil water content (SWC) within the lysimeter was monitored using the neutron back-scattering technique with a neutron moisture probe (Model 503 DR Hydroprobe moisture gauge: Boart Longyear, Martinez, California). Two access tubes were placed $0.5 \mathrm{~m}$ from each vine within the lysimeter (approximately $1.0 \mathrm{~m}$ between the two tubes beneath the drip line) and inserted to a depth of $1.5 \mathrm{~m}$. Readings were taken at depths of $0.23,0.46,0.76,1.07$, and $1.37 \mathrm{~m}$ from the soil surface. Field capacity of this soil type was approximately 22.8 percent by volume $\left(\theta_{\mathrm{v}}\right)$, while SWC at a soil moisture tension of $-1.5 \mathrm{MPa}$ was approximately $8.0 \theta_{\mathrm{v}}$ (Araujo et al. 1995).

A comparison of midday $\Psi_{1}$ and $g_{\mathrm{s}}$ between the two vines growing in the lysimeter and vines growing elsewhere in the vineyard were made in response to: (1) the termination of irrigation during the first dry-down period and (2) the continued irrigation of vines during both drydown periods. The vineyard was divided into quadrants and irrigation terminated in 3, half-rows during the first drydown period, beginning August 24 (DOY 236). The continuously irrigated vines were in the same half-row in which the lysimeter was located during both dry-down periods.

The irrigation pump for the rest of the vineyard, to include the row the lysimeter was located, was controlled by the lysimeter's datalogger (Campbell Scientific $21 \mathrm{X}$ Micrologger, Logan, Utah). Whenever vines within the lysimeter used $2 \mathrm{~mm}$ of water, the vineyard pump was activated and an irrigation event took place with an equivalent amount of water; $8 \mathrm{~L}$ vine ${ }^{-1}$. The activation of a solenoid valve at the head of the row provided the appropriate amount of applied water. An in-line water meter upstream from the solenoid valve measured actual applied water amounts. It should be pointed out that the amount of water applied to these vines, once the lysimeter pump was turned off, slowly decreased and was less than that normally applied to vines at full $\mathrm{ET}_{\mathrm{c}}$.

Data were analyzed via correlation analysis or regression analysis using linear, quadratic, cubic, or other terms. Values presented in the figures represent the means of measurements from the two lysimeter-grown vines for midday $\Psi_{1}$ and $g_{\text {s }}$ versus $\mathrm{ET}_{\mathrm{LYS}}$ on the day measurements were taken. Measurements of $\Psi_{1}$ and $g_{\text {s }}$ taken on vines growing outside the lysimeter represent the means of 6 individual replicates for $\Psi_{1}$ and 9 for $g_{\mathrm{s}}$ (two and three measurements per row for the vines outside the lysimeter for $\Psi_{1}$ and $g_{\mathrm{s}}$, respectively). Differences in $\Psi_{1}$ and $g_{\mathrm{s}}$ between days or measurements made on vines in the lysimeter, the irrigated vines or the nonirrigated vines located elsewhere in the vineyard were analyzed via analysis of variance and means separated using Tukey's test.

\section{Results}

Maximum daily water use by the lysimeter vines during 2005 was almost $50 \mathrm{~L}_{\text {vine }}{ }^{-1}$ on July 24 th $\left(\mathrm{ET}_{\mathrm{o}}=6.85\right.$ $\mathrm{mm}$ ), while mean daily $\mathrm{ET}_{\mathrm{LYS}}$ was approximately $40 \mathrm{~L}$ vine $^{-1}$ just prior to turning the lysimeter pump off (Fig. 1). Subsequently, $\mathrm{ET}_{\mathrm{LYS}}$ decreased to $22.3 \mathrm{~L}$ vine ${ }^{-1}$ nine days later, increased to $30 \mathrm{~L}$ vine ${ }^{-1}$ upon re-watering, and it ultimately decreased to $10 \mathrm{~L}_{\text {vine }}{ }^{-1}$ at the end of the study just before turning the pump back on. During this time frame, $\mathrm{ET}_{\mathrm{o}}$ ranged from greater than $6 \mathrm{~mm}$ per day to less than $3 \mathrm{~mm}$ per day. The $\mathrm{ET}_{\mathrm{LYS}} / \mathrm{ET}_{\mathrm{o}}$ ratio was greater than 0.85 on August 26th and decreased to 0.53 and 0.39 on the last dates of the first and second dry-down periods, respectively. The $\mathrm{ET}_{\mathrm{LYS}} / \mathrm{ET}_{\mathrm{o}}$ ratio increased from 0.75 to 0.85 when the plastic was rolled back to the edges of the lysimeter on DOY 256 and 257 and then back to 0.75 when the soil was covered again.

The uppermost soil depth was saturated with water when the vines were being irrigated (Fig. 2). The two uppermost soil depths experienced the greatest variation in $\theta_{\mathrm{v}}$ during the course of the study, while the lowest depth varied only slightly during the first dry-down period. During the second dry-down period, $\theta_{\mathrm{v}}$ decreased at all depths. The mean $\theta_{\mathrm{v}}$ decreased shortly after irrigation was terminated during 


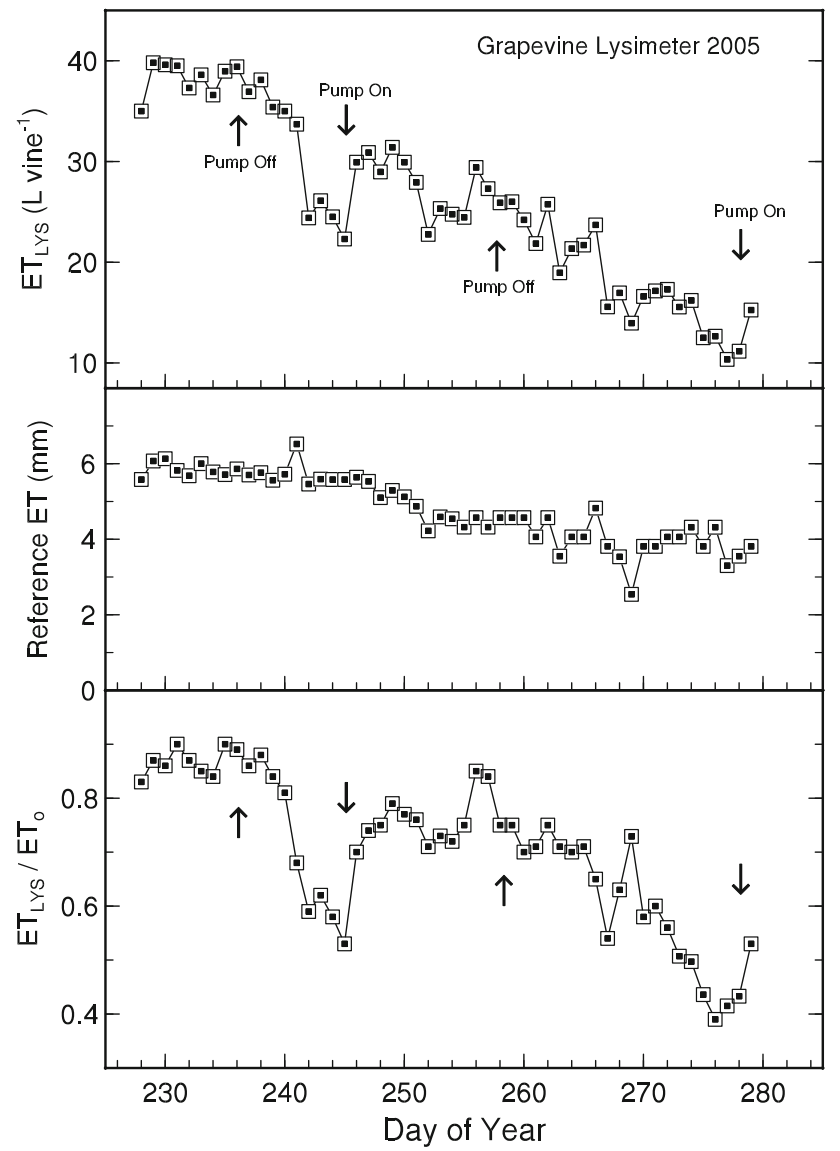

Fig. 1 Daily grapevine lysimeter water use $\left(\mathrm{ET}_{\mathrm{LYS}}\right)$, reference ET $\left(\mathrm{ET}_{\mathrm{o}}\right.$ ), and the $\mathrm{ET}_{\mathrm{LYS}} / \mathrm{ET}_{\mathrm{o}}$ ratio measured from August 16 (DOY 228) to October 6 (DOY 279) in 2005. The arrows indicate the days in which the lysimeter pump was turned off or on during the study. The plastic covering the soil surface of the lysimeter was rolled back to the edges on the morning of September 15 (DOY 256) and back over the soil surface late afternoon on September 16 (DOY 257). The value of $\mathrm{L} \mathrm{d}^{-1}$ divided by 7.55 equals $\mathrm{mm} \mathrm{d}^{-1}$. Fruit from the vines was harvested September 30 (DOY 273)

both dry-down periods. The decrease in $\theta_{\mathrm{v}}$ from August 24 th to September 2 nd and from September 15 th to October 5th was equivalent to 222 and $302 \mathrm{~L}$ vine $^{-1}$ (assuming a rooting volume of $6 \mathrm{~m}^{3}$ vine $^{-1}$ ), respectively. The cumulative $\mathrm{ET}_{\mathrm{LYS}}$ values during the same time frames were 294 and $374 \mathrm{~L}_{\text {vine }}{ }^{-1}$, respectively.

Hourly $\mathrm{ET}_{\mathrm{LYS}}$ of the vines having received no applied water for 9 days (September 2) increased to $90 \%$ of the daily maximum (which occurred at $1300 \mathrm{~h}$ ) by $1100 \mathrm{~h}$ and started to decrease by $1400 \mathrm{~h}$ (Fig. 3). This differed from hourly $\mathrm{ET}_{\mathrm{LYS}}$ data collected earlier (August 23-26) where the daily maximum occurred at $1400 \mathrm{~h}$ and $\mathrm{ET}_{\mathrm{LYS}}$ at $1100 \mathrm{~h}$ was only $76 \%$ of the daily maximum. The diurnal time course of $\mathrm{ET}_{\mathrm{LYS}}$ from September 11 to 15 (Fig. 4) mimicked that of the irrigated vines in August with the hourly maximum occurring at $1400 \mathrm{~h}$. Toward the end of the second dry-down period, $\mathrm{ET}_{\mathrm{LYS}}$ at $1100 \mathrm{~h}$ was $94 \%$ of the

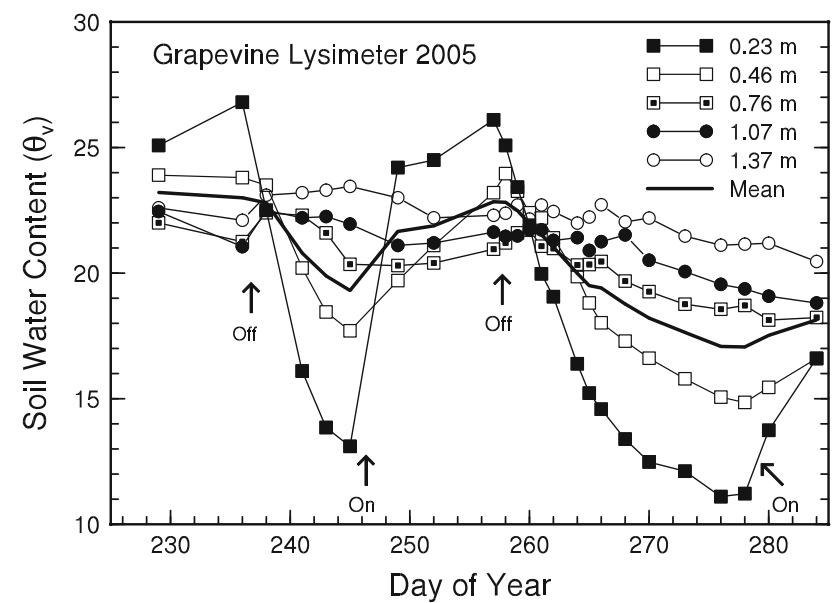

Fig. 2 Soil water content $\left(\theta_{v}\right)$ measured in the lysimeter at five depths from August 28 to October 11 in 2005. The mean $\theta_{\mathrm{v}}$ of the five depths is also given. The arrows indicate the dates in which the lysimeter pump was turned off and on. The scale on the $x$ axis is the same as that in Fig. 1

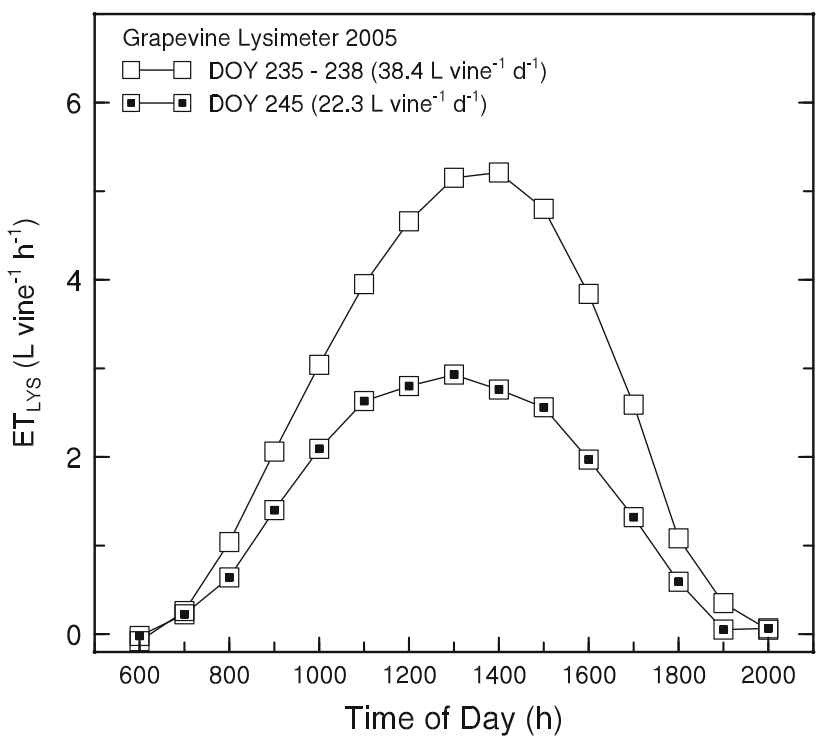

Fig. 3 The diurnal course of hourly $\mathrm{ET}_{\mathrm{LYS}}$ measured from two days before to two days after the irrigation pump was turned off (August 23-26; DOYs 235-238) and the day before the pump was turned back on (September 2; DOY 245). The pump was turned off at $1700 \mathrm{~h}$ on August 24. Hourly data points for DOYs 235-238 and the daily $\mathrm{ET}_{\mathrm{LYS}}$ values given in the figure are the means of those days. Daily $\mathrm{ET}_{\mathrm{o}}$ for DOYs 235-238 and for DOY 245 was 5.76 and $5.58 \mathrm{~mm}$, respectively. Maximum ambient temperature, solar radiation, and vapor pressure deficit for the two data sets were 36.0 and $35.5^{\circ} \mathrm{C}, 874$ and $834 \mathrm{~W} \mathrm{~m}^{-2}$, and 5.11 and $4.47 \mathrm{kPa}$, respectively. All days were cloud free

maximum, which occurred at $1200 \mathrm{~h}$ and had decreased to $76 \%$ of maximum by $1500 \mathrm{~h}$. There was a significant $(P<0.001)$ linear relationship between daily $\mathrm{ET}_{\mathrm{LYS}_{\mathrm{S}}} / \mathrm{ET}_{\mathrm{o}}$ and midday (1200-1400 h) $\mathrm{ET}_{\mathrm{LYS}} / \mathrm{ET}_{\mathrm{o}}$ during the course 


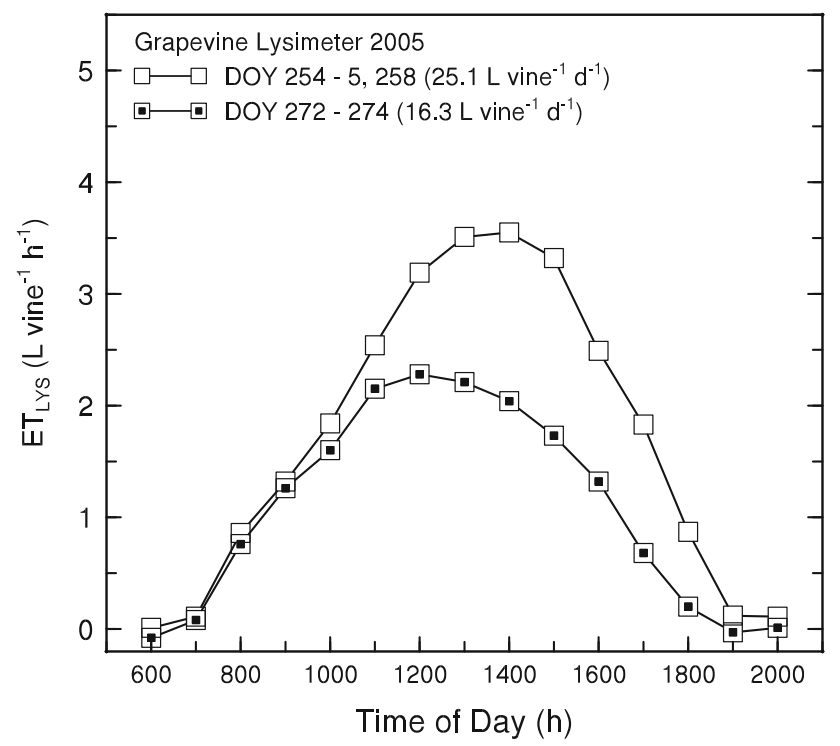

Fig. 4 The diurnal course of hourly $\mathrm{ET}_{\mathrm{LYS}}$ measured two days before (September 11 and 12; DOY 254 and 255) and the day after the irrigation pump was turned off a second time (September 15; DOY 258) and from September 29 to October 1 (DOYs 272-274). The pump was turned off at $1700 \mathrm{~h}$ on September 14. Hourly data points and the daily $\mathrm{ET}_{\mathrm{LYS}}$ values given in the figure are the means of those days. Mean daily $\mathrm{ET}_{\mathrm{o}}$ for DOYs 254, 255 and 258 and for DOYs 272-274 was 4.48 and $4.15 \mathrm{~mm}$, respectively. Mean daily maximum ambient temperature, solar radiation, and vapor pressure deficit for the two data sets were 29.1 and $32.5^{\circ} \mathrm{C}, 784$ and $727 \mathrm{~W} \mathrm{~m}^{-2}$, and 2.76 and $3.47 \mathrm{kPa}$, respectively. All days were cloud free

of the study (midday $\mathrm{ET}_{\mathrm{LYS}} / \mathrm{ET}_{\mathrm{o}}=-0.13+1.25 \times$ daily $\left.\mathrm{ET}_{\mathrm{LYS}} / \mathrm{ET}_{\mathrm{o}}, r=0.97\right)$.

Pre-dawn leaf $\Psi\left(\Psi_{\mathrm{PD}}\right)$ and midday $\Psi_{1}$ on the day prior to turning the lysimeter's irrigation pump off were -0.075 and $-0.75 \mathrm{MPa}$, respectively (Fig. 5). The value of midday $\Psi_{1}$ decreased to $-1.28 \mathrm{MPa} 9$ days later and rapidly increased to values similar to those measured earlier once irrigation resumed. There was a significant $(P<0.001)$ decrease in midday $\Psi_{1}$, from -0.76 to $-0.94 \mathrm{MPa}$, for vines being irrigated outside the lysimeter during the first dry-down period ( $\Psi_{\mathrm{PD}}$ was $-0.09 \mathrm{MPa}$ on the date midday $\Psi_{1}$ was $\left.-0.94 \mathrm{MPa}\right)$. As pointed out in the Materials and Methods while these vines were being irrigated daily, it was with water amounts at less than full $\mathrm{ET}_{\mathrm{c}}$ (water application amounts controlled by the lysimeter). For example, those vines had been irrigated five times per day on August 24th, while only three times per day on August 31 st and September 2nd. The lowest values of $\Psi_{\mathrm{PD}}$ and $\Psi_{1}$ for the lysimeter vines during the second dry-down period were -0.29 and $-1.25 \mathrm{MPa}$, respectively.

The variation in midday values of $g_{\mathrm{s}}$ for the lysimetergrown vines during the study mimicked those of midday $\Psi_{1}$ (Fig. 5). Consequently, midday $g_{\mathrm{s}}$ and $\Psi_{1}$ were highly correlated with one another (Fig. 6). There was also a significant $(P<0.001)$ correlation between $g_{\mathrm{s}}$ and $\Psi_{1}$ for

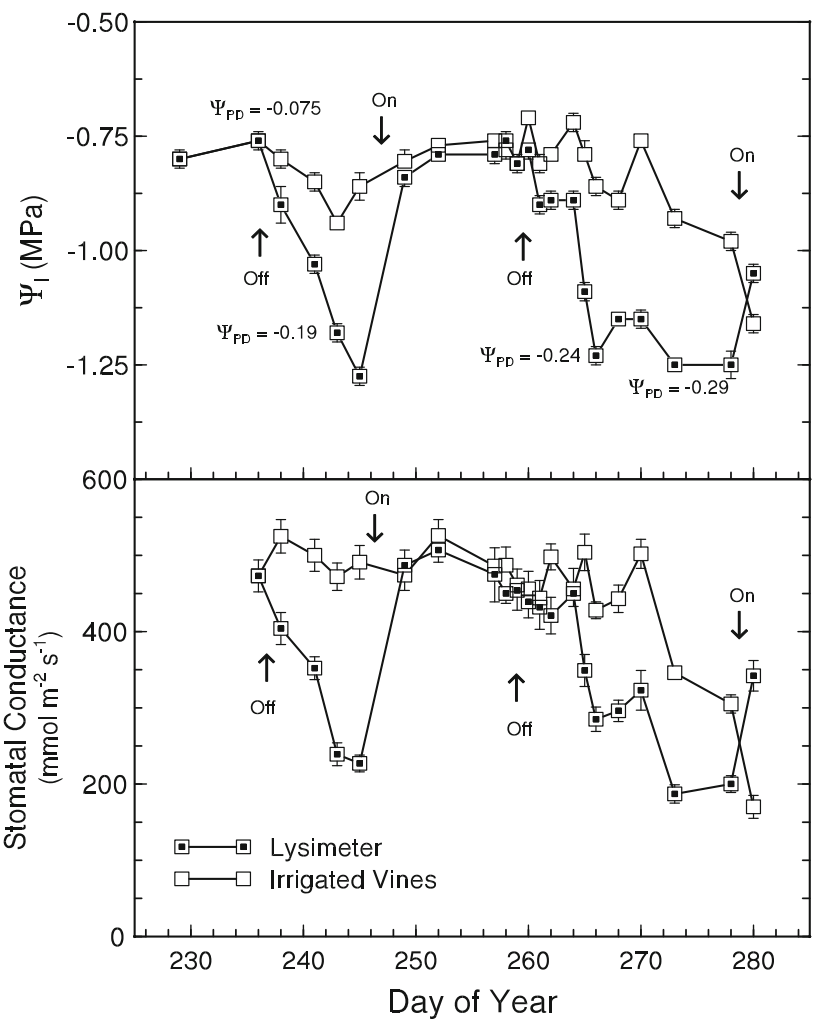

Fig. 5 Midday leaf water potential $\left(\Psi_{1}\right)$ and stomatal conductance $\left(g_{\mathrm{s}}\right)$ measured during the course of the study. Data points are the means of individual measurements taken on leaves from the two vines growing in the lysimeter or irrigated vines growing outside the lysimeter. Bars represent one standard error and are shown when larger than the symbol. On the day in which the lysimeter pump was turned back on at the end of the study, water applications to the vines growing outside the lysimeter were terminated. The values of $\Psi_{\mathrm{PD}}$ (MPa) measured during the study are directly to the left, above or below corresponding $\Psi_{1}$ data points within the figure. The scale on the $x$ axis is the same as that in Fig. 1. Other information is as given in Fig. 1

the irrigated vines grown outside the lysimeter $\left(g_{\mathrm{s}}=\right.$ $\left.1037+406 \times \Psi_{1}, r=0.85\right)$. In addition, there was a significant $(P<0.001)$ correlation between $g_{\mathrm{s}}$ and $\Psi_{\mathrm{PD}}$ using the $8 \Psi_{\mathrm{PD}}$ data points from the lysimeter vines and the irrigated vines $\left(g_{\mathrm{s}}=1199+530 \times \Psi_{\mathrm{PD}}, r=0.91\right)$.

Midday $\Psi_{1}$ and $g_{\mathrm{s}}$ were significantly lower for the nonirrigated vines growing outside the lysimeter on DOYs 238-241 during the first dry-down period when compared to the two vines in the lysimeter on those dates (Table 1). Subsequently, there were no significant differences in $\Psi_{1}$ and $g_{\mathrm{s}}$ between those two sets of vines on DOYs 243 and 245. The vines within the vineyard did not receive additional water once irrigations resumed on September 3rd and this is reflected in significantly lower values of $\Psi_{1}$ and $g_{\mathrm{s}}$ on DOY 245 for these vines compared to the lysimeter vines.

There was a significant linear relationship between the $\mathrm{ET}_{\mathrm{LYS}} / \mathrm{ET}_{\mathrm{o}}$ ratio and midday measurements of $g_{\mathrm{s}}$ (Fig. 7) 


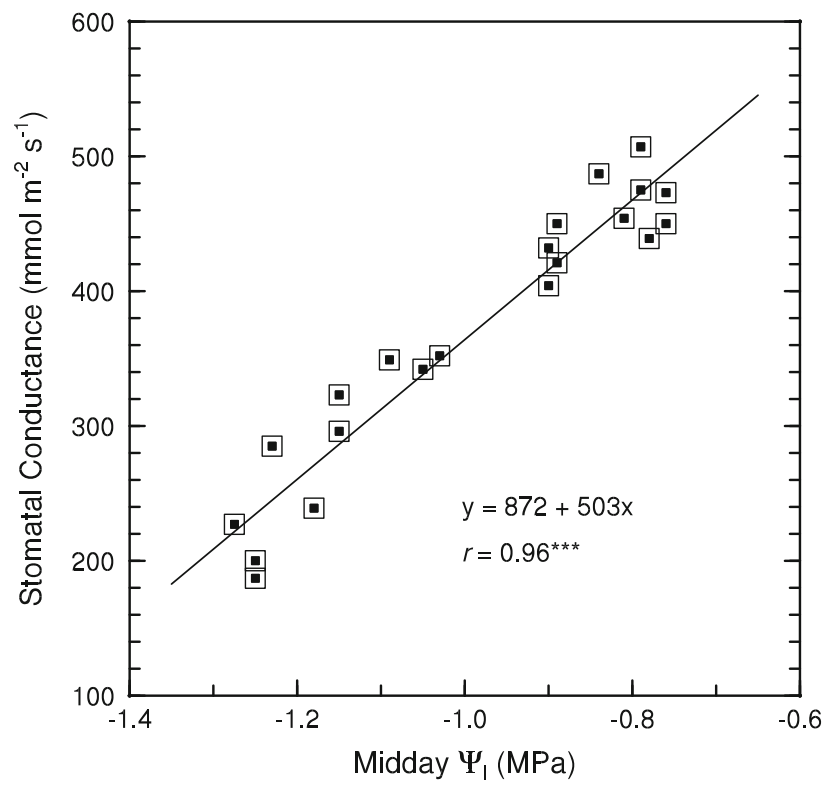

Fig. 6 The relationship between midday leaf water potential $\left(\Psi_{1}\right)$ and stomatal conductance $\left(g_{\mathrm{s}}\right)$ measured on the two vines growing in the lysimeter during the course of the study. Data are those found in Fig. 5

and $\Psi_{1}$ (Fig. 8) with similar correlation coefficients for both. The correlation coefficients between midday measurements of $g_{\mathrm{s}}$ and $\Psi_{1}$ and daily grapevine water use (expressed as $\mathrm{L}$ vine $^{-1}$ ) were only 0.54 and 0.58 , respectively. The difference between measured $\Psi_{1}$ and the calculated $\Psi_{1}$ baseline for fully irrigated vines was also significantly correlated with the $\mathrm{ET}_{\mathrm{LYS}} / \mathrm{ET}_{\mathrm{o}}$ ratio (Fig. 9), and the correlation coefficient was slightly greater than that for the midday $\Psi_{1}$ comparison with the $\mathrm{ET}_{\mathrm{LYS}} / \mathrm{ET}_{\mathrm{o}}$ ratio (Fig. 8). The relationship between the $\mathrm{ET}_{\mathrm{LYS}} / \mathrm{ET}_{\mathrm{o}}$ ratio and $\Psi_{\mathrm{PD}}$ (using the $4 \Psi_{\mathrm{PD}}$ data points given in Fig. 5 for the lysimeter vines) was also significant $\left(\mathrm{ET}_{\mathrm{LYS}} /\right.$ $\left.\mathrm{ET}_{\mathrm{o}}=1.0+1.68 \times \Psi_{\mathrm{PD}}, r=0.96, P<0.05\right)$.

There was a slight difference in the coefficient of determination for a linear relationship between mean $\theta_{\mathrm{v}}$ and the $\mathrm{ET}_{\mathrm{LYS}} / \mathrm{ET}_{\mathrm{o}}$ ratio and a non-linear one (Fig. 10). Lastly, both midday measurements of $\Psi_{1}$ and $g_{\mathrm{s}}$ were significantly $(P<0.001)$ correlated with mean $\theta_{\mathrm{v}}$ over the course of the study $(r=0.87$ and 0.82 for the correlation between $\Psi_{1}$ and $g_{\mathrm{s}}$ and mean $\theta_{\mathrm{v}}$ measured at all depths, respectively).

\section{Discussion}

The significant correlations between midday $\Psi_{1}$ and $g_{\mathrm{s}}$ and midday $\Psi_{1}$ (and $g_{\mathrm{s}}$ ) and the $\mathrm{ET}_{\mathrm{LYS}} / \mathrm{ET}_{\mathrm{o}}$ ratio found in this study were similar to those of Mata et al. (1999). They found that the decrease in daily peach (Prunus persica L.) tree transpiration (measured with a weighing lysimeter)
Table 1 Comparisons of midday leaf water potential $\left(\Psi_{1}-\mathrm{MPa}\right)$ and stomatal conductance $\left(g_{\mathrm{s}}-\mathrm{mmol} \mathrm{m} \mathrm{m}^{-2} \mathrm{~s}^{-1}\right)$ for the lysimeter-grown vines and vines growing in the surrounding vineyard receiving no water during the first dry-down period (1st ddp)

\begin{tabular}{lllll}
\hline $\begin{array}{l}\text { Day of } \\
\text { year }\end{array}$ & $\begin{array}{l}\text { Parameter } \\
\text { measured }\end{array}$ & $\begin{array}{l}\text { Lysimeter } \\
\text { vines }\end{array}$ & $\begin{array}{l}\text { Vineyard vines } \\
\text { (1st ddp) }\end{array}$ & $\begin{array}{l}\text { No applied } \\
\text { water vines }\end{array}$ \\
\hline 236 & $\Psi_{1}$ & -0.83 & -0.83 & -1.32 \\
& $g_{\mathrm{s}}$ & 573 & 602 & 116 \\
238 & $\Psi_{1}$ & $-0.90 \mathrm{a}$ & $-1.04 \mathrm{~b}$ & - \\
& $g_{\mathrm{s}}$ & $504 \mathrm{a}$ & $398 \mathrm{~b}$ & - \\
241 & $\Psi_{1}$ & $-1.03 \mathrm{a}$ & $-1.12 \mathrm{~b}$ & -1.39 \\
& $g_{\mathrm{s}}$ & $-{ }^{\mathrm{a}}$ & - & - \\
$243^{\mathrm{b}}$ & $\Psi_{1}$ & -1.18 & -1.20 & - \\
& $g_{\mathrm{s}}$ & 239 & 203 & - \\
245 & $\Psi_{1}$ & -1.28 & -1.29 & - \\
& $g_{\mathrm{s}}$ & 257 & 229 & - \\
249 & $\Psi_{1}$ & $-0.84 \mathrm{a}$ & $-0.95 \mathrm{~b}$ & - \\
& $g_{\mathrm{s}}$ & $500 \mathrm{a}$ & $437 \mathrm{~b}$ & - \\
251 & $\Psi_{1}$ & -0.79 & -0.77 & -1.32 \\
& $g_{\mathrm{s}}$ & 507 & 521 & 159
\end{tabular}

Water applications were terminated on August 24 (DOY 236) at $1700 \mathrm{~h}$. Values of $\Psi_{1}$ and $g_{\mathrm{s}}$ measured on vines within the vineyard surrounding the lysimeter that had received no applied water at any time during the 2005 growing season are shown for comparison

Values in the 'Parameter measured' rows of the 'Lysimeter vines' and 'Vineyard vines (1st ddp) columns followed by a different letter are significantly different at the $P<0.05$ level. Values in the rows of the same two columns not followed by a letter are not significantly different

a Not measured

b Pre-dawn leaf water potential for the lysimeter vines, vineyard vines (1st ddp), and vines receiving no applied water season long were $-0.19,-0.19$ and $-0.41 \mathrm{MPa}$, respectively, on DOY 243

was linearly related to midday $\Psi_{\text {stem }}$ during a dry-down period of 20 days (deficit irrigation followed by no-irrigation). The relationship between lysimeter grapevine $\Psi_{\text {stem }}$ and $\mathrm{ET}_{\mathrm{LYS}} / \mathrm{ET}_{\mathrm{o}}$ would probably have been similar to that of Mata et al. (1999) in this study if $\Psi_{\text {stem }}$ had been measured as it and $\Psi_{1}$ are highly correlated with one another in grapevines (Salón et al. 2005; Stevens et al. 1995; Williams and Araujo 2002; Williams and Trout 2005). Mata et al. (1999) also found that tree water use and $\Psi_{\text {stem }}$ were highly correlated with soil water content, similar to that found in this study for $\Psi_{1}$ and $g_{\text {s }}$ and soil water content. Williams and Trout (2005) previously had found that midday $\Psi_{\text {stem }}$ and $\Psi_{1}$ were highly correlated with soil water content when measured throughout the season in this same vineyard. Lastly, it has been demonstrated that the $\mathrm{ET}_{\mathrm{c}} / \mathrm{ET}_{\mathrm{o}}$ ratio was linearly related to $\Psi_{\mathrm{PD}}$ of table grapes grown in Italy (Rana et al. 2004). A similar result was found in this study, albeit using only four values of $\Psi_{\mathrm{PD}}$. 


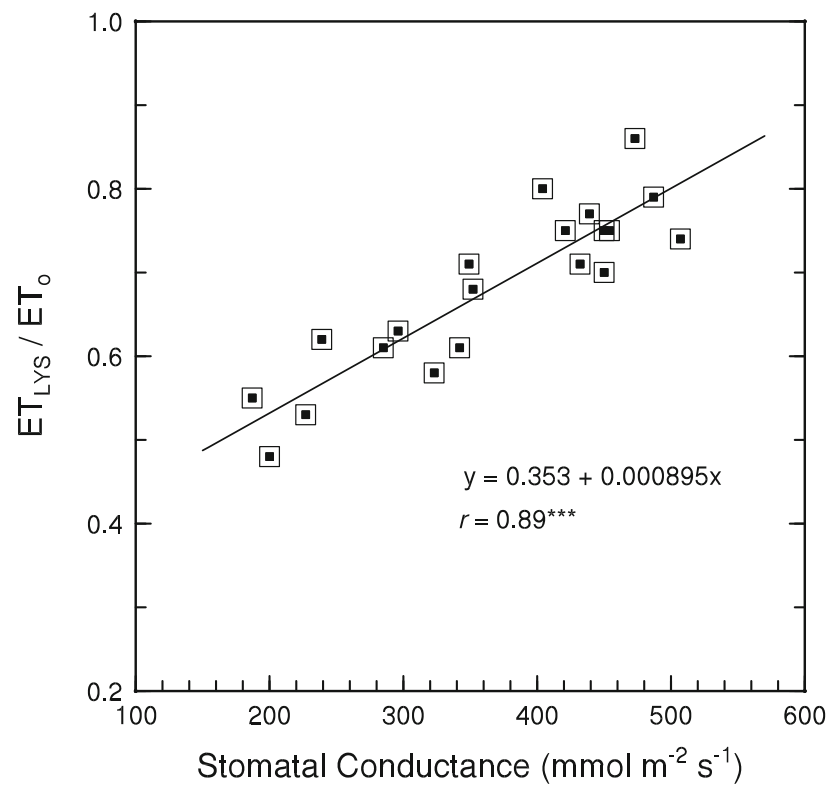

Fig. 7 The relationship between midday stomatal conductance $\left(g_{\mathrm{s}}\right)$ and the $\mathrm{ET}_{\mathrm{LYS}} / \mathrm{ET}_{\mathrm{o}}$ ratio measured during the course of the study. The $\mathrm{ET}_{\mathrm{LYS}} / \mathrm{ET}_{\mathrm{o}}$ data are those calculated on the day midday $g_{\mathrm{s}}$ was measured

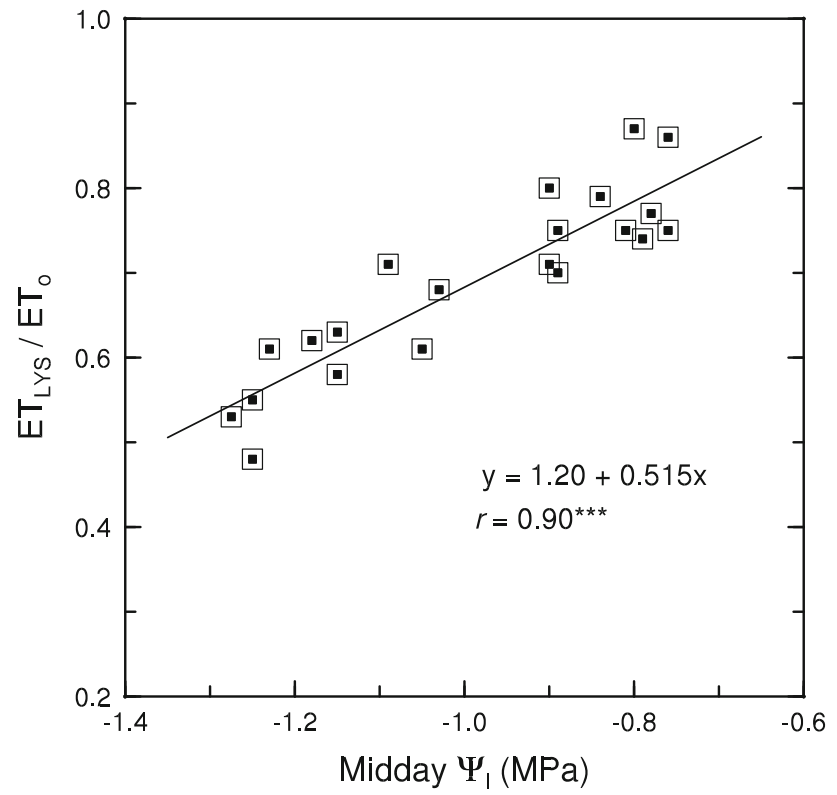

Fig. 8 The relationship between midday leaf water potential $\left(\Psi_{1}\right)$ and the $\mathrm{ET}_{\mathrm{LYS}} / \mathrm{ET}_{\mathrm{o}}$ ratio measured during the course of the study. The $\mathrm{ET}_{\mathrm{LYS}} / \mathrm{ET}_{\mathrm{o}}$ data are those calculated on the day midday $\Psi_{1}$ was measured

There are a few studies in which short-term measures of plant water status and daily or hourly whole plant water use, measured with sap flow sensors, have been compared in grapevines. Sousa et al. (2006) found that sap flow of grapevines measured at $1400 \mathrm{~h}$ was significantly correlated $(r=0.75)$ with $\Psi_{1}$ measured at $1400 \mathrm{~h}$ but not with $g_{\mathrm{s}}$

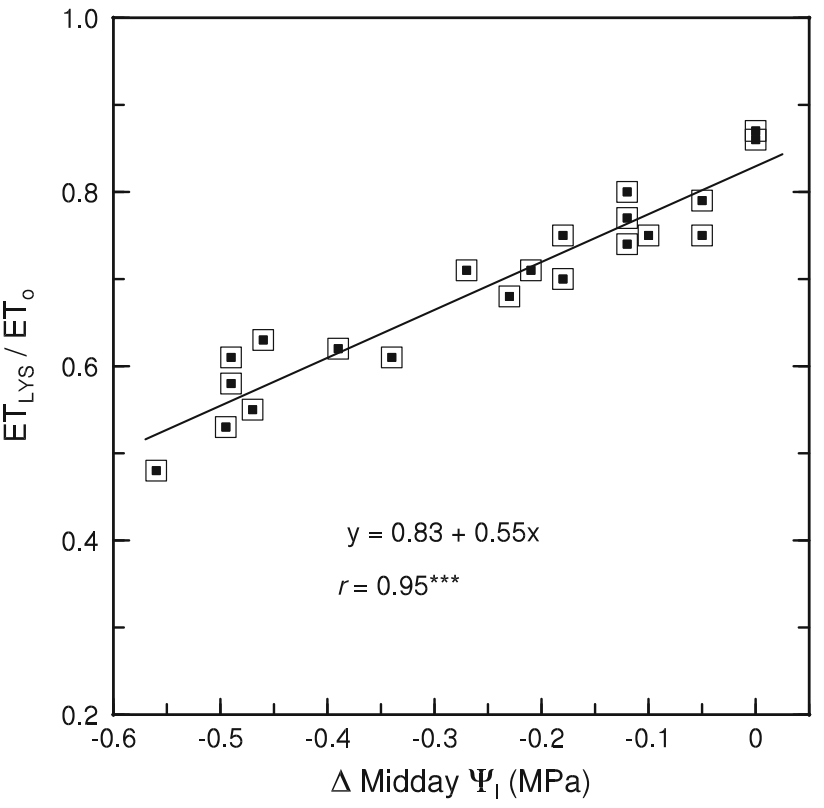

Fig. 9 The relationship between the difference in the calculated $\Psi_{1}$ of a fully irrigated grapevine as a function of vapor pressure deficit (VPD) at the time of measurement and the actual value of $\Psi_{1}$ measured on that day and the $\mathrm{ET}_{\mathrm{LYS}} / \mathrm{ET}_{\mathrm{o}}$ ratio during the course of the study. See "Materials and methods" section for the derivation of the relationship between $\Psi_{1}$ of fully irrigated grapevines and VPD at the time of measurement

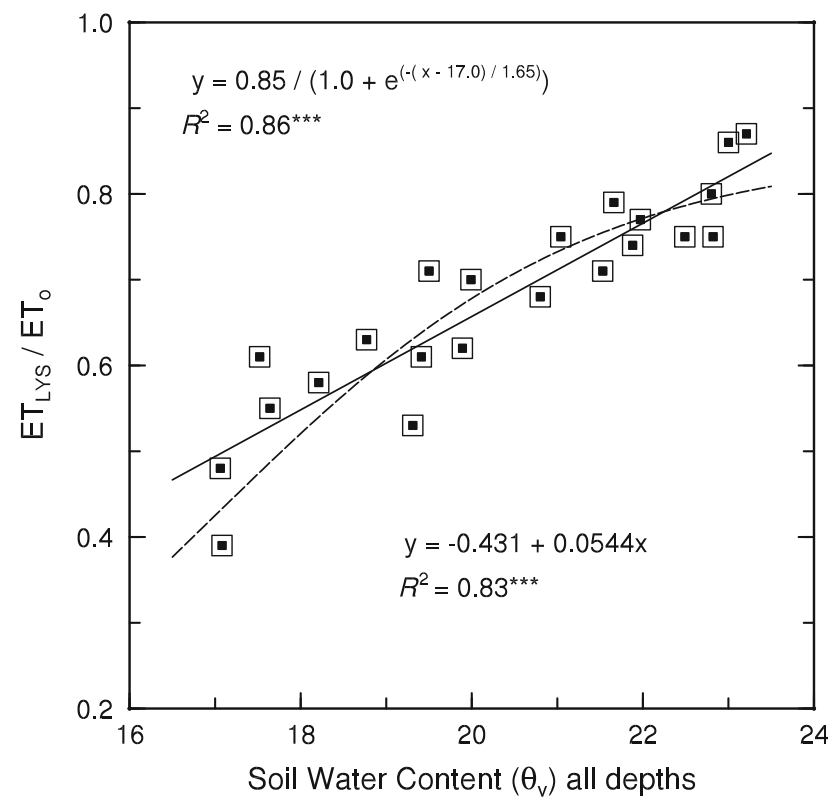

Fig. 10 The linear relationship and the best fit of a non-linear relationship between mean soil water content and the $\mathrm{ET}_{\mathrm{LYS}} / \mathrm{ET}_{\mathrm{o}}$ ratio

measured at the same time. They also found that sap flow and $\Psi_{1}$ measured at $1400 \mathrm{~h}$ were significantly correlated with soil water content. In that study, mean $\Psi_{1}$ measured at $1400 \mathrm{~h}$ was -1.17 and $-1.45 \mathrm{MPa}$ for the fully irrigated and non-irrigated treatments, respectively. Patakas et al. 
(2005) found that the ratio of the mean daily sap flow of their water stressed vines $\left(\mathrm{SF}_{\mathrm{Ti}}\right)$ divided by the mean daily sap flow of their fully irrigated vines $\left(\mathrm{SF}_{\mathrm{Tl}}\right)$ was highly correlated $\left(R^{2}=0.83\right)$ with midday measurements of $\Psi_{\text {stem }}$ ranging from -0.35 to $-1.15 \mathrm{MPa}$. No such relationship was found when the ratio was compared to measures of $\Psi_{1}$ (midday $\Psi_{1}$ averaged $-1.45 \mathrm{MPa}$ for all treatments in that study). Escalona et al. (2002) found that sap flow and short-term measures of leaf $g_{\mathrm{s}}$ and transpiration of irrigated and non-irrigated, potted grapevines differed significantly, but $\Psi_{1}$ did not differ between the two treatments.

While the Sousa et al. (2006) study somewhat agrees with results presented in this paper (relationship between midday $\Psi_{1}$ and grapevine water use) those of Patakas et al. (2005) and Escalona et al. (2002) do not. One possible explanation for the differences between the two latter studies mentioned above and this study could be related to the method and/or technique in which $\Psi_{1}$ was measured. It has been demonstrated that the failure to enclose the leaf blade in a plastic bag just prior to cutting the petiole can dramatically affect the values of $\Psi_{1}$ one measures (Turner and Long 1980). For example, the senior author of this study found that midday $\Psi_{1}$ of fully irrigated vines used in this study on a high evaporative day was $0.6 \mathrm{MPa}$ lower for leaves that were not bagged versus bagged leaves $(-1.3$ vs. $-0.7 \mathrm{MPa}$, respectively). In addition, the difference in $\Psi_{1}$ values between bagged and non-bagged leaf blades is greater in rapidly transpiring leaves compared to those that are not (Turner and Long 1980; Williams and Araujo 2002). Leaf $\Psi$ was measured in the Sousa et al. (2006) study by enclosing the leaf blade in a plastic bag prior to cutting the petiole (noted in their "Materials and methods" section). Patakas et al. (2005) only enclosed the leaves in plastic bags after severing the petiole (personal communication). The exact technique used to measure $\Psi_{1}$ in the Escalona et al's (2002) paper was not given but based upon the above discussion and the results from the measurements of $\Psi_{1}$ from their study, it can be assumed that they did not bag the leaf blade prior to cutting the petiole, probably resulting in erroneous values. In addition, since $\Psi_{1}$ and $\Psi_{\text {stem }}$ are highly correlated with one another in grapevine (Salón et al. 2005; Stevens et al. 1995; Williams and Araujo 2002; Williams and Trout 2005), it is not surprising that Patakas et al. (2005) did not find $\Psi_{1}$ to be correlated with the $\mathrm{SF}_{\mathrm{Ti}} / \mathrm{SF}_{\mathrm{Tl}}$ ratio since they did not measure $\Psi_{1}$ as outlined by Turner and Long (1980). Alternatively, measuring grapevine transpiration via the sap flow technique could have underestimated grapevine water use resulting in unreliable values (Shackel et al. 1992; Tarara and Ferguson 2001).

It has been suggested that $\Psi_{1}$ is not a sensitive water stress indicator for woody horticultural crops (Higgs and
Jones 1990; Jones 1990; 2004; Noar 1998) or that $\Psi_{\text {stem }}$ is a better indicator of plant stress than $\Psi_{1}$ for deciduous tree crops (McCutchan and Shackel 1992; Shackel et al. 1997) or grapevines (Chone et al. 2001; Patakas et al. 2005). Others feel that $\Psi_{\mathrm{PD}}$ is a better indicator of grapevine water status (Cifre et al. 2002; Medrano et al. 2003; Schultz 2003). Jones (2004) pointed out that temporal fluctuations, such as passing clouds, make the interpretation of $\Psi_{1}$ measured during the day as an indicator of irrigation need unsatisfactory. We assume that the same would be true for the use of $\Psi_{\text {stem. }}$. Jones (2004) also mentioned that such an indicator requires a reference or threshold value to be useful in irrigation scheduling. In the arid southern San Joaquin Valley of California, cloud cover is the exception during the summer months. During the course of this study (from August 16 until October 6), there was only one day in which clouds were present. Thus, the measurement of midday $\Psi_{1}$ and $g_{\text {s }}$ occurred at non-limiting light levels. A fully irrigated baseline of $\Psi_{1}$ (and $\Psi_{\text {stem }}$ ) as a function VPD at the time of measurement has been developed for grapevines (Williams and Baeza 2007). This is similar to that developed for trees using $\Psi_{\text {stem }}$ as a function of VPD (McCutchan and Shackel 1992; Shackel et al. 1997). It was shown here that the $\mathrm{ET}_{\mathrm{LYS}} / \mathrm{ET}_{\mathrm{o}}$ ratio was more highly correlated with the difference in the calculated $\Psi_{1}$ of a fully irrigated grapevine as a function of VPD and the actual value of $\Psi_{1}$ measured on the vines in the lysimeter during the course of this study than with measurements of midday $\Psi_{1}$.

Flexas and Medrano (2002) suggested that stomatal closure is one of the earliest responses of plants to drought and the dominant limitation to photosynthesis at mild to moderate drought. Jones (2004) also indicated that over short time-scales, stomata are sensitive indicators of water deficits. The linear decrease in $g_{\mathrm{s}}$ (and $\mathrm{ET}_{\mathrm{c}} / \mathrm{ET}_{\mathrm{o}}$ ratio) with $\Psi_{1}$ reported in this study would indicate that measurements of midday $\Psi_{1}$ reflect the reductions in both individual leaf $g_{\text {s }}$ and whole plant transpiration due to soil water deficits. The same could be said for midday $\Psi_{\text {stem }}$ in the study by Mata et al. (1999). Shackel (2007) also found that there was a linear relationship $\left(R^{2}=0.88\right)$ between $g_{\text {s }}$ and $\Psi_{1}$ of Pinot noir grapevines. These results differ from conclusions by Lovisolo et al. (2010) who after a review of the literature stated that there is no clear relationship between $g_{\mathrm{s}}$ and $\Psi_{1}$ in grapevines and that $g_{\mathrm{s}}$ is better correlated with $\Psi_{\mathrm{PD}}$. The correlations between $\Psi_{1}$ and $g_{\mathrm{s}}$ in this study and those found by Shackel (2007) are better than those between $\Psi_{\mathrm{PD}}$ and $g_{\mathrm{s}}$ reported by Lovisolo et al. (2010), Medrano et al. (2003) and de Souza et al. (2005).

Stomatal control of leaf transpiration can affect plant tissue water status in response to various environmental and soil factors (Jones 1998). Plant species may respond differently to these stresses and have been categorized as 'isohydric' in which stomatal control maintains midday $\Psi_{1}$ 
similarly across varying soil water deficits and 'anisohydric' in which less stomatal control allows for midday $\Psi_{1}$ to decrease in response to soil water deficits (Tardieu and Simonneau 1998). It is often assumed that grapevines (Vitis spp.) are isohydric (Medrano et al. 2003; Patakas et al. 2005) or near-isohydric (Cifre et al. 2005) due to the fact that midday $\Psi_{1}$ doesn't differ between vines that are 'wellwatered' or 'irrigated' and those experiencing soil water deficits. If this were the case, then midday $\Psi_{1}$ measurements could not be used in an irrigation management program. Others have found that some cultivars of $V$. vinifera should be categorized as isohydric while other cultivars anisohydric (Schultz 2003; Vandeleur et al. 2009). However, Soar et al. (2006) stated that grapevines may be categorized as generally anisohydric. Williams and Baeza (2007) concluded that Cabernet Sauvignon, Merlot and Thompson Seedless grapevines should be classified as anisohydric based upon significant differences in midday $\Psi_{1}$ of well-watered vines compared to vines receiving no applied water or were being deficit irrigated (leaf blades were covered with a plastic bag prior to severing the petiole and putting both in the pressure chamber in that study when $\Psi_{1}$ was measured). The data presented in this study would confirm that Thompson Seedless was an anisohydric cultivar. Midday $\Psi_{1}$ progressively decreased subsequent to the irrigation pump being turned off, and it was highly correlated with decreases in both single leaf $g_{\mathrm{s}}$ and the $\mathrm{ET}_{\mathrm{LYS}} / \mathrm{ET}_{\mathrm{o}}$ ratio.

The diurnal patterns of water use for the lysimeter vines when being irrigated (Figs. 3 and 4) are typical to those one would expect for latent heat flux of a well-watered crop (Allen et al. 1998). These patterns coincide with diurnal solar radiation values similar to that shown in Williams et al. (2003b). Conversely, maximum hourly water use of the vines plateau earlier in the day during the first drydown period and hourly water use began to decrease by $1200 \mathrm{~h}$ (PDT) at the end of the second dry-down period in this study. These diurnal patterns for both fully irrigated and stressed vines in this study are similar to those reported by Mata et al. (1999) on peach trees grown in a weighing lysimeter prior to and during a dry-down period, respectively. The diurnal patterns of water use during both the irrigated and non-irrigated periods of this study differ from diurnal patterns obtained in several studies where sap flow sensors were used to quantify grapevine transpiration (Lopes et al. 2004) even those for supposed, well-watered vines (Lu et al. 2003; Patakas et al. 2005; Yunusa et al. 2000). In many of those studies, sap flow is maximized between 0800 and $1000 \mathrm{~h}$, remains constant thereafter, and then decreases rapidly later in the afternoon. It is also interesting to point out that grapevine transpiration in those studies differs only slightly from one day to the next even though evaporative demand changes significantly from one day to the next. The differences between the diurnal patterns of grapevine water use found in this study and Williams et al. (2003b) and those reported elsewhere using sap flow sensors would indicate that the latter technique may not accurately measure whole vine transpiration (Tarara and Ferguson 2001; Shackel et al. 1992) and casts doubt on values of grapevine water use others have reported.

The differences in diurnal water use of vines irrigated at $\mathrm{ET}_{\mathrm{c}}$ and that after the irrigation pump was turned off are similar to those reported by Williams and Ayars (2005a) for vines prior to and after the trunks were girdled (removal of the phloem from around the trunk), respectively. Girdling grapevines will reduce leaf $g_{\mathrm{s}}$ (Harrell and Williams 1987; Hofacker 1978; Kriedemann and Lenz 1972; Roper and Williams 1989), and it will remain lower until the girdle heals (Williams et al. 2000). Therefore, diurnal and daily water use of girdled vines will be lower than vines that are not girdled (Williams and Ayars 2005a). It is thought that girdling reduces $g_{\mathrm{s}}$ due to an accumulation of abscisic acid (ABA) in the leaves of grapevines (During 1978; Loveys and Kriedemann 1974; Williams et al. 2000). ABA has also been implicated in reducing $g_{\mathrm{s}}$ of grapevines in response to soil and atmospheric water deficits and the classification of grapevine cultivars as being either isohydric or anisohydric (Schultz 2003; Soar et al. 2004, 2006). Interestingly, $\Psi_{1}$ is greater for girdled grapevines compared to those that are not girdled due to a reduction in transpiration (Roper and Williams 1989; Williams and Ayars 2005a; Williams et al. 2000). Thus, a reduction in $g_{\mathrm{s}}$ due to girdling will keep $\Psi_{1}$ values higher than those of non-girdled vines, while a reduction in $g_{\mathrm{s}}$ due to soil water deficits in this study did not increase $\Psi_{1}$. There is evidence that plant hydraulic conductance may also play a role in the response of plants to soil water deficits and their classification as isohydric or anisohydric (Franks et al. 2007; Lovisolo et al. 2010; Schultz 2003). This may account for the results presented in this study.

Schultz and Stoll (2010) consider a $\Psi_{\mathrm{PD}}$ value in the vicinity of $-0.2 \mathrm{MPa}$ as no stress for field-grown grapevines. Ojeda et al. (2001) have categorized the level of water deficit experienced by grapevines with a $\Psi_{\mathrm{PD}}$ value of $-0.2 \mathrm{MPa}$ or greater as 'nil', while the level of water deficit experienced by vines with $\Psi_{\mathrm{PD}}$ values between -0.2 and $-0.4 \mathrm{MPa}$ as 'weak'. Studies that have examined water relations in grapevines often report $\Psi_{\mathrm{PD}}$ values for their 'fully irrigated' vines as being close to $-0.2 \mathrm{MPa}$ or lower (Chaves et al. 2007; Correia et al. 1995; de Souza et al. 2005). Data presented in this study indicated as $\Psi_{\mathrm{PD}}$ decreased from -0.07 to -0.19 during the first dry-down period, the $\mathrm{ET}_{\mathrm{LYS}} / \mathrm{ET}_{\mathrm{o}}$ ratio decreased $40 \%$. The $\mathrm{ET}_{\mathrm{LYS}}$ / $\mathrm{ET}_{\mathrm{o}}$ ratio from September 15 to October 3, second drydown period, decreased from 0.75 to 0.39 , a $48 \%$ reduction when $\Psi_{\mathrm{PD}}$ decreased to $-0.29 \mathrm{MPa}$. A reduction in the $\mathrm{ET}_{\mathrm{LYS}} / \mathrm{ET}_{\mathrm{o}}$ ratio of $40 \%$ at a $\Psi_{\mathrm{PD}}-0.19 \mathrm{MPa}$ is 
considerable, not nil, while a reduction in the ratio of $48 \%$ at a $\Psi_{\mathrm{PD}}$ of -0.29 certainly isn't a weak level of water deficit. In addition, grapevines with $g_{\mathrm{s}}$ values decreasing from $200-500 \mathrm{mmol} \mathrm{H}_{2} \mathrm{O} \mathrm{m} \mathrm{m}^{-2} \mathrm{~s}^{-1}$ to $150 \mathrm{mmol} \mathrm{H}_{2} \mathrm{O}$ $\mathrm{m}^{-2} \mathrm{~s}^{-1}$ are assumed to undergo a mild water stress with $g_{\mathrm{s}}$ values between 50 and $150 \mathrm{mmol} \mathrm{H}_{2} \mathrm{O} \mathrm{m}^{-2} \mathrm{~s}^{-1}$ considered a moderate stress (Lovisolo et al. 2010). In this particular study, a reduction in $g_{\mathrm{s}}$ from $\sim 500 \mathrm{mmol} \mathrm{H}_{2} \mathrm{O} \mathrm{m}^{-2} \mathrm{~s}^{-1}$ to just less than $200 \mathrm{mmol} \mathrm{H}_{2} \mathrm{O} \mathrm{m}^{-2} \mathrm{~s}^{-1}$ decreased the $\mathrm{ET}_{\mathrm{c}} /$ $\mathrm{ET}_{\mathrm{o}}$ ratio greater than $40 \%$. It would appear that the current values of $g_{\mathrm{s}}$ assumed by many to indicate no or minimal water stress in grapevine needs to be reexamined.

The majority of grapevines planted on a worldwide basis are located in semi-arid to arid regions, locations with little or no rainfall during late spring and summer and with minimal cloud-cover. The results presented in this study would indicate that the measurement of midday $\Psi_{1}$ is a sensitive indicator of vine water status and a reflection of daily water use of grapevines under the arid conditions of the San Joaquin Valley. Measurements of $\Psi_{1}$ have been successfully used to indicate the water status/irrigation needs of apple trees grown in an arid region (Peretz et al. 1984) or to schedule deficit irrigation in a semi-arid region of Spain (Girona et al. 2006). Grimes and Williams (1990) reported that yield was highly correlated with seasonal mean values of $\Psi_{1,} g_{\mathrm{s}}$ and the crop water stress index (CWSI). They also found that $\Psi_{1}$ and CWSI were highly correlated with one another (unpublished data). Williams et al. (2010a, b) found that both vegetative and reproductive growth of Thompson Seedless grapevines grown in the San Joaquin Valley were linearly related to seasonal, mean values of midday $\Psi_{1}$. Therefore measurements of midday $\Psi_{1}$ ( or $\Psi_{\text {stem }}$ ), or their departure from a fully irrigated baseline $\Psi_{1}$ as a function of VPD, could be used in a vineyard irrigation management program or to validate new stress monitoring techniques under arid or semi-arid growing conditions.

Acknowledgments This study was funded in part by grants from the American Vineyard Foundation, Viticulture Consortium and the California Competitive Grants for Viticulture and Enology. Dr. Baeza was supported by a grant from the Programa Nacional para la Movilidad de Profesores de Universidad del Ministerio de Educación y Ciencia de España.

Open Access This article is distributed under the terms of the Creative Commons Attribution Noncommercial License which permits any noncommercial use, distribution, and reproduction in any medium, provided the original author(s) and source are credited.

\section{References}

Allen RA, Pereira LS, Raes D, Smith M (1998) Crop evapotranspiration: guidelines for computing crop water requirements. (FAO irrigation and drainage paper 56) FAO, Rome
Araujo F, Williams LE, Grimes DW, Matthews MA (1995) A comparative study of young 'Thompson Seedless' grapevines under drip and furrow irrigation. I. Root and soil water distributions. Sci Hortic 60:235-249

Chaves MM, Santos TP, Souza CR, Ortuño MF, Rodriques ML, Lopes CM, Maroco JP, Pereira JS (2007) Deficit irrigation in grapevines improves water-use efficiency while controlling vigour and production quality. Ann Appl Biol 150:237-252

Chone X, Van Leeuwen C, Dubourdieu D, Gaudillere JP (2001) Stem water potential is a sensitive indicator for grapevine water status. Ann Bot 87:477-483

Cifre J, Bota J, Secalona JM, Medrano H, Flexas J (2005) Physiological tools for irrigation scheduling in grapevine (Vitis vinifera L.). An open gate to improve water-use efficiency. Agric Ecosyst Environ 106:159-170

Correia JJ, Pereira JS, Chaves MM, Rodriques ML, Pacheco CA (1995) ABA xylem concentrations determine maximum daily leaf conductance of field-grown Vitis vinifera L. plants. Plant Cell Environ 18:511-521

de Souza CR, Maroco JP, dos Santos TP, Rodrigues ML, Lopes C, Pereira JS, Chaves MM (2005) Control of stomatal aperture and carbon uptake by deficit irrigation in two grapevine cultivars. Agric Ecosyst Environ 106:261-274

During H (1978) Studies on the environmentally controlled stomatal transpiration in grape vines. II. Effects of girdling and temperature. Vitis 17:1-9

Escalona J, Flexas J, Medrano H (2002) Drought effects on water flow, photosynthesis and growth of potted grapevines. Vitis 41:57-62

Fereres E, Soriano MA (2007) Deficit irrigation for reducing agricultural water use. J Exp Bot 58:147-159

Flexas J, Medrano H (2002) Drought-inhibition of photosynthesis in $\mathrm{C}_{3}$ plants: stomatal and non-stomatal limitations revisited. Ann Bot 89:183-189

Franks PJ, Drake PL, Froend RH (2007) Anisohydric but isohydrodynamic: seasonally constant plant water potential gradient explained by a stomatal control mechanism incorporating variable plant hydraulic conductance. Plant Cell Environ 30:19-30

Girona J, Mata M, Del Campo J, Arbonés A, Bartra E, Marsal J (2006) The use of midday leaf water potential for scheduling deficit irrigation in vineyards. Irrig Sci 24:115-127

Grimes DW, Williams LE (1990) Irrigation effects on plant water relations and productivity of 'Thompson Seedless' grapevines. Crop Sci 30:255-260

Harrell DC, Williams LE (1987) Net $\mathrm{CO}_{2}$ assimilation rate of grapevine leaves in response to trunk girdling and gibberellic acid application. Plant Physiol 83:457-459

Higgs KH, Jones HG (1990) Response of apple rootstocks to irrigation in south-east England. J Hortic Sci 65:129-141

Hofacker W (1978) Investigation on the photosynthesis of vines. Influence of defoliation, girdling and removal of grapes. Vitis $17: 10-22$

Jones HG (1990) Physiological aspects of the control of water status in horticultural crops. HortSci 25:19-26

Jones HG (1998) Stomatal control of photosynthesis and transpiration. J Exp Bot 49:387-398

Jones HG (2004) Irrigation scheduling: advantages and pitfalls of plant-based methods. J Exp Bot 55:2427-2436

Kriedemann PE, Lenz F (1972) The response of vine leaf photosynthesis to shoot tip excision and stem cincturing. Vitis 11:193-197

Larus JL (2004) The problems of sustainable water use in the Mediterranean and research requirements for agriculture. Ann Appl Biol 144:259-272

Lopes C, Monteiro A, Ruchert FE, Gruber B, Steinbery B, Schultz HR (2004) Transpiration of grapevines and co-habitating cover 
crop and weed species in a vineyard. A "snapshot" at diurnal trends. Vitis 43:111-117

Loveys BR, Kriedemann PE (1974) Internal control of stomatal physiology and photosynthesis I. Stomatal regulation and associated changes in endogenous levels of abscisic and phaseic acids. Austral J Plant Physiol 1:407-415

Lovisolo C, Perrone I, Carra A, Ferrandion A, Flexas J, Medrano H, Schubert A (2010) Drought-induced changes in development and function of grapevine (Vitis spp.) organs and in their hydraulic and non-hydraulic interactions at the whole-plant level: a physiological and molecular update. Funct Plant Biol 37:98-116

Lu P, Yunusa ISA, Walker RR, Miller WJ (2003) Regulation of canopy conductance and transpiration and their modeling in irrigated grapevines. Funct Plant Biol 30:689-698

Mata M, Girona J, Goldhamer D, Fereres E, Cohen M, Johnson S (1999) Water relations of lysimeter-grown peach trees are sensitive to deficit irrigation. Calif Agric 53(4):17-21

McCutchan H, Shackel KA (1992) Stem-water potential as a sensitive indicator of water stress in prune trees (Prunus domestica L. cv. French). J Am Soc Hortic Sci 117:607-611

Medrano H, Escalona JM, Cifre J, Bota J, Flexas J (2003) A ten-year study on the physiology of two Spanish grapevine cultivars under field conditions: effects of water availability from leaf photosynthesis to grape yield and quality. Funct Plant Biol 30:607-619

Morison JIL, Baker NR, Mullineaus MP, Davies WJ (2008) Improving water use in crop production. Phil Trans R Soc B 363:639-658

Naor A, Gal Y, Peres M (2006) The inherent variability of water stress indicators in apple, nectarine and pear orchards, and the validity of a leaf-selection procedure for water potential measurements. Irrig Sci 24:129-135

Ojeda H, Deloire A, Carbonneau A (2001) Influence of water deficits on grape berry growth. Vitis 40:141-145

Patakas A, Noitsakis B, Chouzouri A (2005) Optimizations of irrigation water use in grapevines using the relationship between transpiration and plant water status. Agric Ecosyst Environ 106:253-259

Peretz J, Evans RG, Proebsting EL (1984) Leaf water potentials for management of high frequency irrigation on apples. Trans Am Soc Agric Eng 27:83-90

Rana G, Katerji N, Introna M, Hammami A (2004) Microclimate and plant water relationship of the "overhead" table grape vineyard managed with three different covering techniques. Sci Hortic 102:105-120

Roper TR, Williams LE (1989) Net $\mathrm{CO}_{2}$ assimilation and carbohydrate partitioning of grapevine leaves in response to trunk girdling and gibberellic acid application. Plant Physiol 89:1136-1140

Salón JL, Chirivella C, Castel JR (2005) Response of cv. Bobal to timing of deficit irrigation in Requena, Spain: Water relations, yield and wine quality. Am J Enol Vitic 56:1-8

Schultz HR (2003) Differences in hydraulic architecture account for near-isohydric and anisohydric behaviour of two field-grown Vitis vinifera L. cultivars during drought. Plant Cell Environ 26:1393-1405

Schultz HR, Stoll M (2010) Some critical issues in environmental physiology of grapevines: future challenges and current limitations. Austral J Grape Wine Res 16:4-24

Shackel KA (2007) Water relations of woody perennial plant species. J Int Sci Vigne Vin 41:121-129

Shackel KA, Johnson RS, Medawar CK, Phene CJ (1992) Substantial errors in estimates of sap flow using the heat balance technique on woody stems under field conditions. J Am Soc Hort Sci 117:351-356
Shackel KA, Ahmadi H, Biasi W, Buchner R, Goldhamer D, Gurusinghe S, Hasey J, Kester D, Krueger B, Lampinen B, McGourty G, Micke W, Mitcham E, Olson B, Pelletrau K, Philips H, Ramos D, Schwankl L, Sibbett S, Synder R, Southwick S, Stevenson M, Thorpe M, Weinbaum S, Yeager J (1997) Plant water status as an index of irrigation need in deciduous fruit trees. HortTechnol 7:23-29

Soar CJ, Speirs J, Maffei SM, Loveys BR (2004) Gradients in stomatal conductance, xylem sap ABA and bulk leaf ABA along canes of Vitis vinifera cv. Shiraz: molecular and physiological studies investigating their source. Funct Plant Biol 31:659-669

Soar CJ, Speirs J, Maffei SM, Penrose AB, McCarthy MGM, Loveys BR (2006) Grape vine varieties Shiraz and Grenache differ in their stomatal response to VPD: apparent links with ABA physiology and gene expression in leaf tissue. Austral J Grape Wine Res 12:2-12

Sousa TA, Oliveira MT, Pereira JM (2006) Physiological indicators of plant water status of irrigated and non-irrigated grapevines in a low rainfall area of Portugal. Plant Soil 282:127-134

Steinberg SL, McFarland MJ, Worthington JW (1990) Comparison of trunk and branch sap flow with canopy transpiration in pecan. J Exp Bot 41:653-659

Stevens RM, Harvey G, Aspinall D (1995) Grapevine growth of shoots and fruit linearly correlate with water stress indices based on root-weighted soil matric potential. Austral J Grape Wine Res 1:58-66

Synder RL, Pruitt WO (1992) Evapotranspiration data management in California. In: Proceedings, Irrigation and drainage sessions/ Water Forum 1992. EE, HY, IR, WR Div/ASCE, Baltimore, MD

Tarara JM, Ferguson JC (2001) Device for simulating high rates of sap flow in grapevines. Am J Enol Vitic 52:260-265

Tardieu F, Simonneau T (1998) Variability among species of stomatal control under fluctuating soil water status and evaporative demand: modelling isohydric and anisohydric behaviours. J Exp Bot 49:419-432

Turner NC, Long MJ (1980) Errors arising from rapid water loss in the measurement of leaf water potential by the pressure chamber technique. Austral J Plant Physiol 7:527-537

van Leeuwen C, Goutouly JP, Costa-Ferreira AM, Asaïs C, Marguerit $\mathrm{E}$, Roby JPh, Choné X, Germain Ch, Homayouni S, Gaudillère JP (2006) Intra-block variations of vine water status in time and space. In: Proceedings VIth international terroir congress, vol 1, 3-5 July. 2006. Bordeaux, France. CENITA, Bordeaux, pp 64-69.

Vandeleur RK, Mayo G, Shelden MC, Gilliham M, Kaiser BN, Tyerman SD (2009) The role of plasma membrane intrinsic protein aquaporins in water transport through roots: diurnal and drought stress responses reveal strategies between isohydric and anisohydric cultivars of grapevine. Plant Physiol 149:445-460

Williams LE (1987) Growth of 'Thompson Seedless' grapevines: I. Leaf area development and dry weigh distribution. J Am Soc Hortic Sci 112:325-330

Williams LE, Araujo F (2002) Correlations among predawn leaf, midday leaf, and midday stem water potential and their correlations with other measures of soil and plant water status in Vitis vinifera L. J Am Soc Hortic Sci 127:448-454

Williams LE, Ayars JE (2005a) Water use of Thompson Seedless grapevines as affected by the application of gibberellic acid $\left(\mathrm{GA}_{3}\right)$ and trunk girdling-practices to increase berry size. Agric For Meteor 129:85-94

Williams LE, Ayars JE (2005b) Grapevine water use and the crop coefficient are linear functions of the shaded area measured beneath the canopy. Agric For Meteor 132:201-211

Williams LE, Baeza P (2007) Relationships among ambient temperature and vapor pressure deficit and leaf and stem water 
potentials of fully irrigated, field-grown grapevines. Am J Enol Vitic 58:173-181

Williams LE, Matthews MA (1990) Grapevine. In: Stewart BA, Nielson DR (eds) Irrigation of agricultural crops-agronomy monograph No. 30. ASA-CSSA-SSSA, Madison, WI, pp 1019-1059

Williams LE, Trout TJ (2005) Relationships among vine and soil based measures of water status in a Thompson Seedless vineyard in response to high frequency drip irrigation. Am J Enol Vitic $56: 357-366$

Williams LE, Retzlaff WA, Yang W, Biscay PJ, Ebisuda N (2000) Effect of girdling on leaf gas exchange, water status and nonstructural carbohydrates of field-grown Vitis vinifera L. (cv. Flame Seedless). Am J Enol Vitic 51:49-54

Williams LE, Phene CJ, Grimes DW, Trout TJ (2003a) Water use of young Thompson Seedless grapevines in California. Irrig Sci $22: 1-9$
Williams LE, Phene CJ, Grimes DW, Trout TJ (2003b) Water use of mature Thompson Seedless grapevines in California. Irrig Sci 22:11-18

Williams LE, Grimes DW, Phene CJ (2010a) The effects of applied water at various fractions of measured evapotranspiration on water relations and vegetative growth of Thompson Seedless. Irrig Sci 43:221-232

Williams LE, Grimes DW, Phene CJ (2010b) The effects of applied water at various fractions of measured evapotranspiration on reproductive growth and water productivity of Thompson Seedless. Irrig Sci 28:233-243

Yunusa IAM, Walker RR, Loveys BR, Blackmore DH (2000) Determination of transpiration in irrigated grapevines: comparision of the heat-pulse technique with gravimetric and micrometeorological methods. Irrig Sci 20:1-8 